European Journal of Turkish Studies

Social Sciences on Contemporary Turkey

5 | 2006

THEMATIC ISSUE

Power, ideology, knowledge - deconstructing Kurdish

Studies

\title{
'I would be sitting in the village room where people gather.' Interview with Martin van Bruinessen
}

Martin van Bruinessen

\section{OpenEdition}

Journals

Electronic version

URL: https://journals.openedition.org/ejts/775

DOI: $10.4000 /$ ejts. 775

ISSN: $1773-0546$

Publisher

EJTS

\section{Electronic reference}

Martin van Bruinessen, "'I would be sitting in the village room where people gather.' Interview with Martin van Bruinessen", European Journal of Turkish Studies [Online], 5 | 2006, Online since 05 March 2015, connection on 10 December 2021. URL: http://journals.openedition.org/ejts/775 ; DOI: https:// doi.org/10.4000/ejts.775 


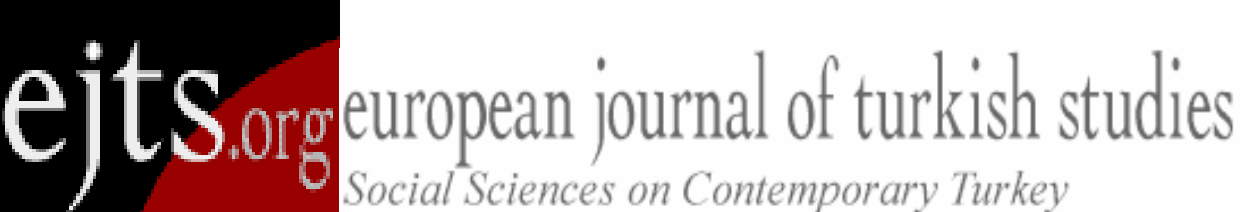

Citation: Bruinessen, Martin Van (2006) 'I would be sitting in the village room where people gather.' Interview with Martin Bruinessen', European Journal of Turkish Studies, Thematic Issue ${ }^{\circ} 5$, Power, ideology, knowledge - deconstructing Kurdish Studies, URL : http://www.ejts.org/document775.html

To quote a passage, use paragraph (§).

\section{'I would be sitting in the village room where people gather.' Interview with Martin Bruinessen}

Martin van Bruinessen

\section{Interview}

Interview conducted by Marie Le Ray, Utrecht, 23/12/06.

EJTS: Could you introduce yourself and let us know more specifically how you got interested in the Kurdish question as a scholar?

[2] Martin Van Bruinessen: It is a story that I have told too many times and it has become perhaps too polished to be exactly what happened. The story that I have told seems to have shaped my memory. Anyway, I was a student of mathematics. I enjoyed travelling. I was going every summer holidays to the Middle East and I often ended up in Iran, Iraq. I remember my first encounter with Kurds was in Baghdad. People that I met there told me about their relatives who were in the mountains fighting against the government, which I found very exciting those days. That was in 1966 or 1967. I think that was the military coup d'état of 1971 in Turkey that gave me a more political interest in Turkey. Initially it has just been a curiosity in exotic places, travel to less accessible parts of the world and so on. After the coup d'état, I began to get more interested in politics, joined a solidarity committee, and befriended political refugees from Turkey. I observed the trials that followed the coup d'état. One of them in particularly drew my attention. That concerned an academic who was sentenced to 13 years in prison for writing a book. That man was İsmail Beşikçi and he had written a sociological book on the Kurds. I remember thinking that if you can get in prison for writing a book on the Kurds, it is obviously an important thing to do, writing a book on the Kurds! (laughing). The case 
Citation: Bruinessen, Martin Van (2006) 'I would be sitting in the village room where people gather.' Interview with Martin Bruinessen', European Journal of Turkish Studies, Thematic Issue $N^{\circ} 5$, Power, ideology, knowledge - deconstructing Kurdish Studies, URL : http://www.ejts.org/document775.html

To quote a passage, use paragraph $(\S)$

of Beşikçi was very important in my decision to take the Kurds as a subject of anthropological investigation. I knew I lived in Holland and I was not going to be imprisoned for writing on the Kurds; but still it seemed something more important than some other subjects.

[3] EJTS: When you started to study on the Kurdish issue, what were your readings? In which languages were you reading?

[4] MVB: It was late 1960's, early 1970's. It was in a period that the student movement was very much interested in the Third World and in the Third World's revolutions, imperialism, liberation struggles, dependency theory. I was reading in English mostly. I read one French author, but in English: Franz Fanon on the Algerian revolution. But mostly, I was reading the British and American neo-Marxists who were theoreticians of imperialism. I was reading journals like New Left Review, Monthly Review and ordinary anthropology.

[5] EJTS: How did these readings influence your theoretical approach of the Kurds? In which terms did you formulate the questions you wanted to ask to your field then?

[6] MVB: I had studied mathematics with some anthropology on the side, and I wanted to do a study that was both quantitative and based on long-term fieldwork. I thought of making a combination of a classical anthropological village study, where the anthropologist lives in a village for, if possible, two years, and an economic analysis of what imperialism and dependency meant at the local level; so an analysis of inputs and outputs, and economic relations combined with relations of political dominance, local power and status. You know that in the Middle East, many theoreticians believe that we don't have really classes, but status is more important than class, and that ethnic groups stand besides one another rather than Kurdish workers, Turkish workers, Persian workers being one class. Within each ethnic group, you have relations of patronage between people, that prevent them from acting on the basis of class interest. Social status, especially in tribal communities, was said to be far more significant than class. But there had been a few peasant uprisings against landlords in the 1950s, both in the Iranian and the Iraqi parts of Kurdistan, that looked very much like class-based movements. And in the 1960s the Shah had carried out a land reform that had created a class of independent landowners. So I was very interested in how all this would look at the local level. My idea was that I was going to live in a village in Iranian Kurdistan for two years to follow two full 
Citation: Bruinessen, Martin Van (2006) 'I would be sitting in the village room where people gather.' Interview with Martin Bruinessen', European Journal of Turkish Studies, Thematic Issue $N^{\circ} 5$, Power, ideology, knowledge - deconstructing Kurdish Studies, URL : http://www.ejts.org/document775.html

To quote a passage, use paragraph $(\S)$

agricultural cycles and observe economic transactions; and I would look at all dependency and patronage relations and so on.

[7] EJTS: What about your scientific advisors, your scientific environment at that time?

[8] MVB: I had a professor of anthropology, who wasn't at all of that school of anthropology. He was a structuralist and he had been a colonial administrator. So he did not really understand what I wanted to do. But he was very supportive nevertheless. And I was very isolated: no one was looking on these things. There was in those days no one in Holland doing anthropology of the Middle East. There was one person who had done a study of a village in Iran but no one else. I was really on my own. I had to think up things alone.

[9] EJTS: How did you plan your fieldwork?

[10] MVB: Well, if you want to do anthropological studies, you need permissions from the government. Anthropologists are not welcome there. In Turkey I could not expect permission to do research on the Kurds. But Turkey wasn't even in my mind. In Iraq - I started planning in the early 1970 s - I knew that a new war was going to break out. So Iran remained. Iran was a pro-Western country, where anthropologists were welcome. Many, especially American, anthropologists were doing village studies there. So I asked for permission in Iran to do research. I was not aware that, even in Iran, you can not study the Kurds. As the permission did not come, I went to Iran just by myself. I told my supervisor I'm going to wait for my permission in Tehran. And I started meeting these American anthropologists there. Everyone was laughing at me because I thought I could study the Kurds: 'Didn't you know you can't study this!?' Fortunately I did not know. So, without permission, I started going to Kurdistan and I was spending weeks and months there. Permission didn't come. I got a rejection, I asked for another permission; I got another rejection, I asked for another new permission. Still they did not kick me out of the country. I could make short visits to the region. I was learning Kurdish in a Kurdish café in Tehran where I sat everyday, speaking to people about the villages they were coming from. I had learnt Persian before going there. I already knew some Turkish, which I learnt also by myself. So I learnt Sorani Kurdish in this coffee house. I got friends in Mahabad. I have been in Mahabad before and I knew some families whom I stayed with and who also helped me make a course of Kurdish for myself. But because I did not get my permission, I couldn't stay for a long time in that place. I had not been arrested but there were often people coming 
Citation: Bruinessen, Martin Van (2006) 'I would be sitting in the village room where people gather.' Interview with Martin Bruinessen', European Journal of Turkish Studies, Thematic Issue $N^{\circ} 5$, Power, ideology, knowledge - deconstructing Kurdish Studies, URL : http://www.ejts.org/document775.html

To quote a passage, use paragraph $(\S)$

up to me telling me I had better move on and I felt this must be SAVAK, the Intelligence service, who told me I couldn't stay. I was a few times interrogated. So I had to move from place to place and never could do the research that I had planned to do. But that was interesting because I started noticing differences between one place and another. Not only differences between, let's say one place, you have one tribe, another place you have a lot of tribes, a third place you don't have tribe at all. You also have different types of power relations. In the course of travelling, I also met Kurds from Iraqi Kurdistan. Meanwhile the war had started and there were refugees in the region, but also lots of Iraqi peshmergas were travelling. Several times I stayed in the same room in a small hotel or guest house with such Iraqi travellers, and when I explained them what I was doing, they would say: 'Why don't you come to Iraqi Kurdistan? We have liberated areas where no government can tell you not to stay!' The Iraqi Kurds had an office in Tehran. So when I was in Tehran again, I went to this office and they gave me permission to research. I think they did not know what anthropological research is. They may have thought I was a sort of journalist or perhaps an Intelligence agent but both were very welcome because they wanted to have good relations with Western countries. Later they probably noticed that anthropologists ask embarrassing questions, but then I was already there.

[11] EJTS: From Iran to Iraq, and then you also did fieldwork in Turkey...

[12] MVB: Yes, I never got my permission in Iran and I was thrust out of Iraqi Kurdistan. I was there in the winter of 1974/75. I remember that on Newroz 1975, we had to live because the Kurds had given up the struggle. They have been abandoned by the Shah and by the Americans. Iranian troops had pulled back and Iran had cut off all support. The Kurds had to give up. About 50000 thousands people fled to Iran and I was with them. Then, I continued doing what I was doing before. I kept travelling through Iranian Kurdistan. Meanwhile my research design had changed; it became much more comparative and less in-depth. Interviews had then become much more important and I was much more focusing on what I could find out about power relations and control over economic resources I decided I would also take Turkey into this comparison and Syria. All together, I did spend my two years in the region, but travelling from one part to the other.

[13] EJTS: What about the specific constraints under which you conducted your fieldworks in these different countries? It seems to have been much easier in Iraq. 
Citation: Bruinessen, Martin Van (2006) 'I would be sitting in the village room where people gather.' Interview with Martin Bruinessen', European Journal of Turkish Studies, Thematic Issue $N^{\circ} 5$, Power, ideology, knowledge - deconstructing Kurdish Studies, URL : http://www.ejts.org/document775.html

To quote a passage, use paragraph $(\S)$

[14] MVB: Yes. Although I had a minder, someone who came with me all the time. But he was young. He was a student himself and he became quite interested into my questions. I remember we started discovering that there were feudal relations, that the peasants were oppressed, exploited by feudal lords. They had to give money but also services to the feudal lords. They were liberated by the Party from the feudal lords. But then they had to give the same services and the same money to the Party! The commanders, people who belonged to the inner circle around Mustafa Barzani, were new regional feudal lords. They were basically doing the same and for the peasants nothing had changed. And my minder, when he started seeing this, became much more critical. He later became one of the early members of PUK (Patriotic Union of Kurdistan) when Talabani organised himself separately in rivalry with the Barzani family.

[15] EJTS: How did the Turkish fieldwork go?

[16] MVB: The first thing I did was I just crossed the border from Iran to Yüksekova. I went to Van and from Van, I went to the South and I walked all the way to Cizre. It was the spring and nomads were staying on the mountains. There was an earlier study about the nomads of that region that I had read, by the German geographer Wolfgang Hütteroth $(1959,1961)$. It is a very important study, very good. I wanted to see the place where he had been and some of these nomads he had written about. For the first time in my life, I slept in a nomads' tent. It felt like there is no police, you are very free. It was long before the PKK (Partiya Karkerên Kurdistan, Party of Kurdistan Workers), it was in 1975. But later I noticed that, after I had been there, the nomads were interrogated about me. The intelligence may not interrogate or imprison me but people I had talked to might be in danger. So I became much more careful after that. In Cizre, I found another protector, a sheikh. I had already met several sheikhs in Iran and my fascination with Sufism had already started. And then I heard there was a family of sheikh. He was a very young man and we liked each other tremendously. We became friends and, because he enjoyed a certain degree of independence, he could afford to have me in his house, and then in his village without too many questions to be asked. And because many people were coming to see them, I could do interviews. Moreover, because of my earlier contacts with political refugees and my work in a solidarity committee I already had some contacts in several places in Turkey, including Diyarbakır, before I started my research. Some of my contacts were school teachers. Before the 1971 Coup, there was a teachers' trade-union. The trade-union was later banned. Teachers not being workers, they had no right to strike. So they don't have a trade-union 
Citation: Bruinessen, Martin Van (2006) 'I would be sitting in the village room where people gather.' Interview with Martin Bruinessen', European Journal of Turkish Studies, Thematic Issue N 5 , Power, ideology, knowledge - deconstructing Kurdish Studies, URL : http://www.ejts.org/document775.html

To quote a passage, use paragraph $(\S)$

anymore, now they have an association, TÖB-DER (Türkiye Öğretmenler Birleşme ve Dayanışma Derneği, Association for Union and Solidarity between Teachers in Turkey). Through this association, I met teachers who were working in villages. I went to several of these villages and staying with the teacher gave me a certain legitimacy. Gradually I learnt sufficient spoken Kurmanci to pass for, well perhaps not a real Kurd but, when I said: 'My father was from here but I grew up in Europe', it was accepted. Anyway, Kurdish is not standardised and people can not imagine that the person who speaks Kurdish is not a Kurd. And I had a large moustache that I thought made me look somewhat like a local; I bought my clothes locally so that it did not look conspicuously different. I had started imitating people body language. I believe I was not very conspicuous. So I could often stay in villages. But there always was Jandarma and sooner or later they would hear there was a stranger in the village; and they would come and ask what he was doing. OK, I was visiting my friend who was a teacher, but how long can you visit a friend. So I had to find different excuses and different places to stay in villages. But it worked. And 1975-1976 was maybe the freest time. After, it became much more difficult to do this.

[17] EJTS: How did you operate concretely to gather data on the field?

[18] MVB: I was making interviews, an interview often being: you have a conversation and in the evening you write your notes. I very rarely taped my interviews. I had a tape-recorder with me but it makes people suspicious, so I did not do this. Much of my work was rather more observing. I would be sitting in the village room where people gather. And if you do follow the conversations, you also notice status difference. It is a wonderful place to study how people locate themselves socially. The social map is projected on the physical plan of this village room. When not everyone is happy with the social order, you can see it. People may even be ready to talk about it, afterwards. I was really so happy doing research there; I felt I was getting into that society, starting to understand. I really liked the people. For my personal development, just as a social person, it was very important. I used to be a very solitary person who enjoyed books much more than human company. When I was doing research, it was a work so I had to do it; I had to learn how to be social with people. I guess that was the Kurds who made me human. So I'm feeling grateful; I mean the Kurds have been very important to me.

[19] EJTS: When and why did you choose Indonesia as another field of investigation? 
Citation: Bruinessen, Martin Van (2006) 'I would be sitting in the village room where people gather.' Interview with Martin Bruinessen', European Journal of Turkish Studies, Thematic Issue $N^{\circ} 5$, Power, ideology, knowledge - deconstructing Kurdish Studies, URL : http://www.ejts.org/document775.html

To quote a passage, use paragraph $(\S)$

[20] MVB: I never chose to work about Indonesia. There was another coup d'état in Turkey in 1980. I heard that my name was on the list of people who are not allowed in Turkey. But that didn't mean much because you could go there very easily if you did not fly in there. They only had computer terminals in Ankara and Istanbul. I could go through Syria or Kuşadası without being noticed. But, in principle, I was not welcome for a while. I had been in Iran during the Revolution and after the Revolution, and then I never got a visa for Iran anymore. I thought I might be black-listed there too. I have been in Iraq again in 1978 or 1979. This is the last time I could go there. Someone who had worked in the Embassy in Holland - who left after it was found out he was secretly working for Talabani - told me that I was blacklisted in Iraq and I was considered a very dangerous Zionist agent! I knew that I would not get permission there anymore. As it looked like I was not very welcome in these countries, I thought I should perhaps relocate. I was putting my hopes in Afghanistan. I have even been doing some work in Afghanistan. Then Russia invaded the country. I could not go there anymore. And I was unemployed. In Holland, you get unemployment benefit only if you keep applying for jobs. I was writing a new research proposal that still have to do with the Kurds, but I had to apply. I got a first job and I rejected it; I got another job, they accepted me and I rejected it. You can only reject twice. The next time, I saw an ad saying they needed a PhD to work on Indonesia. I said I had a PhD, I've never read anything about Indonesia but I was interested in the job. And they said: 'Well, tabula rasa'; they gave me the job. So, I had to decide if I would reject again. So it is not by choice but by accident that I ended up in Indonesia. In the beginning, I thought it would just be a brief interlude for one or two years. But I hung on for more than ten years now. I'm still going there very frequently.

[21] EJTS: Can you make these two fieldworks - Kurdistan and Indonesia - look at each other in some way?

[22] They are very different, very different. In Indonesia, first, I had permission, which gave me guilty feelings. Because when you get permission, somehow, it means you are considered not dangerous. And, on the other hand, it feels like connivance with the regime and I always felt bad about it. It was a bad regime in Indonesia! But they allowed me to do fieldwork and I lived in a poor slum for a year. My formal job description was, to become an expert on Indonesian Islam. I wanted to relate it somehow to developments I had observed in Turkey and Iran. So my question was: Is something like the Iranian Revolution or the rise of the MSP (Milli Selamet Partisi, National Salvation 
Citation: Bruinessen, Martin Van (2006) 'I would be sitting in the village room where people gather.' Interview with Martin Bruinessen', European Journal of Turkish Studies, Thematic Issue $N^{\circ} 5$, Power, ideology, knowledge - deconstructing Kurdish Studies, URL : http://www.ejts.org/document775.html

To quote a passage, use paragraph $(\S)$

Party, 1972-1981) in Turkey or the Islamist groups of Egypt possible in Indonesia? And does it have anything to do with the migration of lower middle class and poor people from small towns to major cities, which many people thought was an explanation of these events. Many of the explanations of the Islamic resurgence in the Middle East involve some variety of relative deprivation theory. I was attracted to the concept of relative deprivation but thought it was used to explain too much and too easily. When you have a group of radicals it is always possible to find some relative deprivation in their personal histories. So I said to myself, why don't we start with the people who must experience most acute relative deprivation and see how they respond religiously. I looked at just one town, just one poor neighbourhood, but there were statistics that I could use. I observed more specifically the people who had moved from richer areas into that neighbourhood, the poorest one. So I lived for a year among the relatively deprived; and again I enjoyed the fieldwork enormously, I was happy. Even though I caught some nasty diseases, just like my neighbours. It was hard from time to time. And of course they proved not to be radical. Poor people can't afford to be radicals. It is the privileged who get radical, privileged people like us. Again, it is a long story, but it is a very different research.

[23] EJTS: What about the comparative dimension of this research that includes Iran and Turkey?

[24] MVB: In the beginning I thought it would be possible, but then, no. There are many comparisons but there are not proper sociological comparisons. I could never do the same sort of research in Turkey as I did in Indonesia. I have a student now who is doing fieldwork among forced migrants in a poor neighbourhood in Istanbul. But again it is rather different. I did try to take the ethnic dimension into account in my work in Indonesia. Perhaps in this desire to compare, I chose the region where there was the second largest ethnic group of Indonesia. In my neighbourhood, the majority also belonged to that group and a smaller number belonged to the largest ethnic group, with smaller numbers of other ethnic backgrounds. But ethnicity or regionalism were not very important. It is a factor but it is working in a very different way in Indonesia. Another comparative observation is, I found myself looking much at Sufi orders. In Kurdistan I had been observing the Sufi orders and their political roles. I found the same Sufi orders in Indonesia. I found moreover that there is an indirect Kurdish influence on Indonesian Islam, especially on Sufism, although no Kurd had ever been there. Indonesians and Kurds met in Mecca or in the Medina. In the past, many Indonesians studied with 
Citation: Bruinessen, Martin Van (2006) 'I would be sitting in the village room where people gather.' Interview with Martin Bruinessen', European Journal of Turkish Studies, Thematic Issue $N^{\circ} 5$, Power, ideology, knowledge - deconstructing Kurdish Studies, URL : http://www.ejts.org/document775.html

To quote a passage, use paragraph $(\S)$

Kurdish teachers in Medina. And Indonesians associate the Kurds with Islam; Kurdi is now also a personal name given to men in pious families.

[25] EJTS: Let's come back to your work on Kurds. In Turkey, you've been first published in Özgür Gelecek, the journal of Mehmet Bayrak. How did you come to this publication?

[26] MVB: He published parts of the book in his journal in 1988 or so, before we got to know each other. He was taken to court over it then. I met him after that, when he was at the point of publishing the entire book. It was not a very good translation and I thought he should wait and have a better translation made but he pushed ahead with it because to him publishing the book was a political statement. I had mixed feelings about it because many passages were mistranslated and it was not a very readable Turkish. The translator was a student of anthropology but she didn't dare to take freedom to translate it. She did it very literally unfortunately. But Bayrak was right that this was the right time to publish such a book. It was such an amazing time, those last years of the Özal period, when issues that had long been taboo could suddenly be discussed in public... I had thought I would never in my life be able to go back officially to Turkey. I was very happy to see that I was in print, that I had started to exist in Turkey, thanks to Mehmet Bayrak. It was probably the first book in Turkey that has the name Kurdistan in its title. It was a breakthrough in a way. I am very proud to have been indirectly the means of Mehmet Bayrak to establish the Kurds in print.

[27] EJTS: What about non-academic research on the Kurdish question? The role of journalists and 'writer-researchers' (araştırmacı-yazar) especially, often Kurds themselves, has been quite determinant in this knowledge production. What kind of use did you make of these sources?

[28] MVB: I do not know who do you think about when you are saying araştırmacı-yazar. Some of them are political ideologists, who invent their own realities, either pro- or anti-Kurdish. But there are many others who have made very valuable contributions. You have local historians like Şevket Beysanoğlu, who has written many books on Diyarbakır. The word 'Kurd' for a long time did not exist in his books. He mentions Armenians though from time to time. I mean if you read his books very carefully, you see that he dared to deal with this issue as early as the 1960s. He explains that after the disappearance of the Armenians, the economy of certain regions collapsed, because certain skills disappeared. He calls the disappearance of the Armenians and economic loss - but he does not say how the Armenians disappeared. As a Turkish speaking Diyarbakırlı he must have had 
Citation: Bruinessen, Martin Van (2006) 'I would be sitting in the village room where people gather.' Interview with Martin Bruinessen', European Journal of Turkish Studies, Thematic Issue $N^{\circ} 5$, Power, ideology, knowledge - deconstructing Kurdish Studies, URL : http://www.ejts.org/document775.html

To quote a passage, use paragraph $(\S)$

ambiguous feelings about Kurdish identity, like Gökalp of whom he was a great admirer. Gökalp himself had a very strong affinity with Kurdish identity although he decided not to be a Kurd but to be a Turk. He was a Türkiyeli and a Diyarbakırlı especially. Very late in life, when the political situation in Turkey changed, Beysanoğlu started to give indications that he was a Kurd really. I think people like him, they have written very important things from an historical and even a social point of view, although they are not sociologists, they are not trained in any academic discipline.

[29] You have many Kurds who are politically committed and, out of political commitment, write about Kurdish history or Kurdish society. Some of them write nonsense, some of them write really good stuff. The best of them, Rohat Alakom and Malmîsanij, have written excellent books that can easily compete with academic writing. They were political exiles in Sweden, of course, and have been able to develop intellectually there. But you also find people who never left Turkey writing fascinating, well-researched books, like Muhsin Kızılkaya's book on social banditry (Kızılkaya 1991) or Müslüm Yücel's book on death, suicide and suicide attacks (Yücel 2003). Or the young self-taught historian Gürdal Aksoy, who had engaged very critically with Kurdish nationalist historiography.

[30]Araştırmacl-yazar have been especially influential in the debates on ethnic and subethnic identity that were so prominent in the 1990s: are the Zazas Kurds or a different people, is Kurdish Alevism different from Turkish Alevism, and so on.

[31] EJTS: How influential have these writers been on public opinion on the Kurdish question?

[32] MVB: The public sphere in Turkey is fragmented; there is not a single public sphere. You have publishers who publish for certain specific audiences and no one else will buy their books. Even today, when it is much more acceptable to talk about Alevis and Kurds and so on, but you still have publishers that publish specifically for Alevi audiences and no one else will buy their books. You have publishers that publish specifically for a Kurdish audience. Avesta publishes excellent books but, unfortunately, I don't think many Turks will even know of its existence. I was so fortunate to meet with Murat Belge and Ömer Laçiner, the people who established İletişim, an important mainstream publisher whose books are read by a broad cross-section of the educated public. By the time they thought it was possible, they decided to publish some of my writings in Turkish. And I think it was very important for me personally as a breakthrough. My first book is a collection of articles and it is 
Citation: Bruinessen, Martin Van (2006) 'I would be sitting in the village room where people gather.' Interview with Martin Bruinessen', European Journal of Turkish Studies, Thematic Issue N 5 , Power, ideology, knowledge - deconstructing Kurdish Studies, URL : http://www.ejts.org/document775.html

To quote a passage, use paragraph $(\S)$

called Kürdistan üzerine yazılar (Van Bruinessen 1992). I think it was the first academic study of Kurds that was read by many Turks who would not read other people's writings. And later they published three other books by me that also sold very well, including a new and much better translation of Agha, Shaikh and State. So I think my friendship with Murat Belge and Ömer Laçiner sort of presented me as someone acceptable. Meanwhile of course, many other people were writing academic books that have been translated and also might be read like Robert Olson's (1993). I proposed to İletişim to publish a collection of Hamit Bozarslan's writings. Hamit is a very good researcher but he is not yet very well known in Turkey unfortunately. For some reason, they never did a book by Hamit. Perhaps is is something to do with their experience with another important book. In 1999 they published Wadie Jwaideh's book on Kurds, a doctoral dissertation from 1960 that was never properly published but that has remained a classic of the history of Kurdish nationalism. (Only this year it was published in English, by Syracuse University Press.) I've never met Jwaideh but I consider him as one of my teachers because I learnt so much from his book. He was an Iraqi Arabicspeaking Christian, a Chaldean born in the south who had, as a civil servant, travelled a lot in Northern Iraq. He had come to know all the major agha and understood how they thought. And then he did research in archives in Britain. He wrote a wonderful history of the emergence of Kurdish nationalism in 1960, before it became a new big political movement. All later researchers are indebted to it, so it was a good idea for Illetişim to publish it in Turkish. But it came out at a wrong time and it was almost immediately banned. I think the ban is by now lifted, but they have not re-printed the book. And I think because of that, they have been a bit reluctant to translate more books on Kurdish nationalism. I had been fortunate to do research at a time that travel was relatively free, and I was fortunate again that my books in Turkey appeared at a time that there was an opening; more things became possible and many people were curious. So I was made famous in Turkey because my books happened to come out at a certain time that there was a demand for it. I believe Iletişim put Hamit's book on hold after the ban of Wadie Jwaideh's book. Otherwise there is no reason why Hamit's writings would not be published. His writings would definitely be acceptable in Turkey, I think, and they are very good.

[33]lt is important with which publisher a book is published. There was for instance a good volume on the Kurds edited by Philip Kreyenbroek and Stefan Sperl (1992) that came out in Turkish 
Citation: Bruinessen, Martin Van (2006) 'I would be sitting in the village room where people gather.' Interview with Martin Bruinessen', European Journal of Turkish Studies, Thematic Issue $N^{\circ} 5$, Power, ideology, knowledge - deconstructing Kurdish Studies, URL : http://www.ejts.org/document775.html

To quote a passage, use paragraph $(\S)$

with another publisher and remained almost unnoticed, even though it was banned for a while. So where the book is published is extremely important in whether it is being taken up or not.

[34] EJTS: What kind of feedback did you get after the publication and translation of your first book Agha, Shaikh and State. On the social and political organisation of Kurdistan?

[35] MVB: I submitted my thesis in 1978 and I privately printed something like 800 copies that somehow found a way to the Kurdish community. So many Kurds knew about the book and you still find older Kurds who still have it at home. Sometimes a student comes to me with one of these: 'I found this copy. Can you sign it for me?' And then, because I had an irregular life and I travelled a lot, I did not find the time to find a publisher until much later. In 1992, it was published at Zed Books, slightly revised and again not a very satisfying edition. I was not around. They needed to correct all the terms I had written in Kurdish. They had someone who knew Arabic and they believed that Kurdish is a sort of Arabic and they 'corrected' many things. I had to un-correct them, even names of people. So I am not very happy with the book anyway. I have friends in Germany who, when I was in Indonesia, had translated it to German. It was again not a very good translation but it made me famous in Germany (a much improved version was published in 2003). Germany has a very large Kurdish community, many students were there. So when I came back from Indonesia, around 1990, I realised that the German translation of the book was going around. From the German it was translated into Sorani later. Later I was offered a job in Berlin, indirectly because of this German translation. For a year (1996-97) I was a visiting professor of Kurdish studies at the Free University of Berlin and I think it was mainly because of this book that I was known in Germany. But you are asking about feedback...

[36] Well, sometimes Kurds write to me or telephone or e-mail me about relatives that they recognize in the book, sometimes to correct me or give me additional information. I have often been asked by Kurdish associations to give a talk. Usually when I get invited by Kurds, I say yes. So l've had many discussions and I have always learnt a lot from confronting my ideas with people. I have sometimes been told, 'there are many books about the Kurdish political movement but yours is one of the very few about our society.' In general, the responses from Kurds have been very positive, even when I am critical of them or their leaders. I was very happy that my book was translated into Turkish so that many of the Kurds of Turkey could read it. The Iraqi translation, it was a bad Sorani 
Citation: Bruinessen, Martin Van (2006) 'I would be sitting in the village room where people gather.' Interview with Martin Bruinessen', European Journal of Turkish Studies, Thematic Issue $N^{\circ} 5$, Power, ideology, knowledge - deconstructing Kurdish Studies, URL : http://www.ejts.org/document775.html

To quote a passage, use paragraph $(\S)$

translation. But there was a translation so people read it also. There is now a very good Persian translation, better than the original. And a new version is coming out in Arabic in Iraq. I think for an anthropologist, it is very important that the people you have studied are able to read what you write about them and to critique you, to engage you in debate. I learn a lot from these things.

[37] EJTS: Do you think that in Turkey, diffusion of the academic knowledge about Kurds has to go through non academic media?

[38] MVB: Yes absolutely. In the case of the Kurds and other ethnic groups in Turkey, recognition and cultural rights will not come automatically. It was because public opinion had come to accept the existence of the Kurds as a self-evident fact that the state was forced to give up its formal denial. We shall see the same in the case of the Armenian question: first the terms of public debate will change, and then policies will be adapted. That makes it important for scholars who are working on these sensitive issues to come out of the ivory tower. Each academic work in this field has political relevance and has potentially political implications. You take part in, it will be too arrogant to say in conscientization - but at least Turkey needs a public debate and I think academics have an important function to play in stimulating such a debate, and giving reasonable arguments. You have of course people who have a rigid political perspective, political purposes and who want to project one particular vision of their truth. I think we as academics should not simply offer our own version of the 'truth' but question official narratives as well as their alternatives, provide good arguments, and especially point to inconvenient facts that are, deliberately or not, neglected.

[39] EJTS: What has been the place of scientific expertise among politics concerning the Kurdish issue and what is it today?

[40] MVB: All governments have an interest in academic work, especially if they can use it as a legitimation for their own policies or if it is useful for the implementation if those policies. Academic work that attempts to change the public discourse that ultimately shapes policies is in a more difficult position. Major policy changes usually have to be forced by a change in public debate. And this is what you see happening. It was not politicians themselves who decided that the Kurdish issue can be debated in public. There was of course a technological change and a privatisation, so satellite televisions arrived and you had private channels in Turkey. Kurds became publicly visible in Turkey thanks to private television, again thanks to Özal. There was a TV program, Siyaset Meydanı, a very 
Citation: Bruinessen, Martin Van (2006) 'I would be sitting in the village room where people gather.' Interview with Martin Bruinessen', European Journal of Turkish Studies, Thematic Issue $N^{\circ} 5$, Power, ideology, knowledge - deconstructing Kurdish Studies, URL : http://www.ejts.org/document775.html

To quote a passage, use paragraph $(\S)$

important program in that time and several discussions in this program contributed to change public debate in Turkey. There was another major event: Mehmet Ali Birand - who was a newspaper journalist, now he works for CNN Türk - made a visit to Öcalan. It was published in Milliyet (on 15 June 1988). On the front page, you see Öcalan playing football and he tells that is a sympathizer of the Galatasaray team. Suddenly the man who was Şeytan (the devil) became a human being like us. Things like this really had a great impact on politics but it goes through the public sphere.

[41] EJTS: How are the Kurdish studies in Holland? With whom did you and are you working with?

[42] MVB: I think I was the first academic in Holland to study the Kurds. But there was a small solidarity committee, the International Society Kurdistan, before I started doing that. This was one man, with a few collaborators, who got interested in the Kurds. He was interested in nationalism and I think he had a strange background, but anyway. He had a huge collection of books and documents on the Kurds, and he published a newsletter on the Kurds. When I became interested, I contacted this man and I learnt quite a bit from him about the Kurds. I did not study Oriental Studies, or any of the relevant languages formally; but fortunately I pick up languages quite easily myself. I was not in contact with any people in the field; I was not even aware there were people doing oriental studies in Holland at that time. My academic background was in mathematics and physics and little bit anthropology. And the anthropologists that I have worked with did their research in very different parts of the world. So I did not start from some background of scholarship about the region; I had to start from scratch. This all changed of course when, in 1975, the first Iraqi Kurdish political refugees, and then in the late 1970s from Turkey started coming. The 1980s saw huge waves of political refugees, among them many Kurds. Because there are many Kurds here, more Dutch people became interested into them.

[41] By the mid-1980s, you find many people eager to learn more about the Kurds and wanting to know the language: social workers, lawyers, human rights activists, people who had struck up a friendship, or a love affair, with Kurds living here. In 1985 I was back in Utrecht for a year or so and I gave a Kurdish language course at the university (in the Department of Arabic, Persian and Turkish Studies). To my surprise, many people followed that course. 
Citation: Bruinessen, Martin Van (2006) 'I would be sitting in the village room where people gather.' Interview with Martin Bruinessen', European Journal of Turkish Studies, Thematic Issue $N^{\circ} 5$, Power, ideology, knowledge - deconstructing Kurdish Studies, URL : http://www.ejts.org/document775.html

To quote a passage, use paragraph $(\S)$

[42] Philip Kreyenbroek, who was then teaching Persian here, became interested in Kurdish, and after my course he started taking up Kurdish. Now he is a professor in Göttingen and the leading Kurdish scholar in Germany. He taught at SOAS (the School of Oriental and African Studies in London) for a while and one of his students there, Christine Allison, is now teaching Kurdish at the INALCO (National Institute of Oriental Languages and Civilisations - Paris). Another student of those early days in Utrecht, Margreet Dorleijn, wrote a very good dissertation in Kurdish linguistics, and taught Turkish and Kurdish at the University of Amsterdam for a while. So gradually you see a whole network emerging. Here in Holland, we have had several solidarity committees, and several members of them have gone on to do academic work on Kurdish subjects. One of my students, Joost Jongerden, started as the Turkey expert for Amnesty International and he travelled a lot in Kurdistan. Earlier this year, he finished a dissertation on the return to the village. He also wrote several articles on the subject and together with Paul White he edited a book on the Alevis. A younger colleague with whom I worked much is Michiel Leezenberg, a philosopher and linguist, who wrote some very good work on Iraqi Kurdistan.

[43] We had several Kurdistan solidarity committees. There was one in the 1970s and one or two people in that committee became journalists who occasionally write about the Kurds and they still maintain their interest in the Kurds. Later there was a more political, left-wing committee. But like the Kurds themselves, these solidarity committees never get together very well. They fall apart, they quarrel and so on. But always, something remains. There have been several journals. In the early 1980s, there was a 'Turkey and Kurdistan' journal in Holland. When the PKK people became more organized, they of course started publishing their own journals. They found some Dutch people who wanted to work with them. But it is a very fragmented pro-Kurdish community. The Kurds are not playing a very important role in publishing here. There are Kurdish students associations, and then you have the PKK and PKK allied associations. The last Kurdistan committee that I was in fell apart because we did not have time and perhaps because we did not share the same perspective. A few of the people who were in this committee still regularly have contact and sometimes we do things together.

[44] Concerning the university more specifically, I came back from Indonesia finally in 1994 and I resettled in Holland. In-between, I had been coming and going but living in Indonesia basically. I got a job here, as a lecturer of Turkish and Kurdish studies at the Department of Arabic, Persian and 
Citation: Bruinessen, Martin Van (2006) 'I would be sitting in the village room where people gather.' Interview with Martin Bruinessen', European Journal of Turkish Studies, Thematic Issue $N^{\circ} 5$, Power, ideology, knowledge - deconstructing Kurdish Studies, URL : http://www.ejts.org/document775.html

To quote a passage, use paragraph $(\S)$

Turkish studies where I had given my first Kurdish course in the mid-1980s. I had also learned Ottoman Turkish there and together with colleagues worked on Evliya Çelebi and other Ottoman sources on the Kurds (Van Bruinessen and Boeschoten, 1988). For a few years I was teaching Kurdish language, Kurdish history alongside Ottoman history and history of the Middle East. But I gradually moved more into Islamic studies because of students' demands and university policies. Presently there are formally no Kurdish studies in Dutch Universities anymore. I supervise a few students who work on the Kurds. But they do this in the framework of a discipline like anthropology or history, not Oriental languages and cultures; they have decided to do a dissertation within that discipline, anthropology, that happens to be about the Kurds.

[45] EJTS: What are the fields of investigation and theoretical framings of these students working on Kurds?

[46] MVB: Well I have very few students working on the Kurds. Joost Jongerden is the one who completed his $\mathrm{PhD}$ on the return to the villages after the forced village evacuations of the 1990s. At the same time, I had another student, Miriam Geerse, who worked on the refugees and displaced people in Istanbul. I have a Turkish student, Seda Altuğ, who works on the memories of the drawing of the Syrian-Turkish border among the different ethnic communities living there. She interviewed mostly Armenians, Suriani and Kurds in Syria and also in the Turkish part. She wants to locate memory also in a historical context. She focuses on the identity narratives that develop to help people define themselves by remembering certain things and forgetting other things. Then another Turkish student, Umut Azak, is working also on the production and uses of memory in Turkish secularism. She studies powerful icons like Said Nursi, the Menemen incident, that are used to represent to everpresent threat to Turkish laicism. And Alevism as a symbol of 'good' Islam. The Kurds play a role in that research but are somewhat marginal. And a Dutch student, Evelyn Hendriks, has recently started a project that she calls 'gender@kurdistan', looking at the use of the Internet in Iranian Kurdistan, combining the approaches of media studies and gender studies with serious anthropological fieldwork.

[47] And then, I have students who do very different things. Most of my Ph.D. students work on other subjects than the Kurds in fact. 
Citation: Bruinessen, Martin Van (2006) 'I would be sitting in the village room where people gather.' Interview with Martin Bruinessen', European Journal of Turkish Studies, Thematic Issue $N^{\circ} 5$, Power, ideology, knowledge - deconstructing Kurdish Studies, URL : http://www.ejts.org/document775.html

To quote a passage, use paragraph $(\S)$

[48] EJTS: Can you see some evolutions in the terms the 'Kurdish question' has been approached and asked? What has changed since you termed the question? How did your own approach of the issue transform in time, if it did?

[49] MVB: In general there have been great changes. The old-fashioned political economy type approaches are not very popular currently. Cultural studies are very prominently present in studies of Turkey. It is partly because there are many young researchers at Boğaziçi, at Marmara and at the other good universities of Istanbul who want to study the Kurdish society and other things that have great relevance, but have to do this in paradigms that are both trendy and unthreatening, so the cultural studies approach is popular. Among Europeans who study the Kurds, many of them have come to these studies also from a background of activism and solidarity. In Germany, that is very strong; they have Kurdish friends or Turkish friends living in Germany and they became active in Human Rights or political solidarity movements. So there is much attention to aspects like civil society, human rights, and women's rights.

[50] Sharzad Mojab, who is a central person in the Kurdish Women's Studies Network, once commented on my first book that it is a completely un-gendered book. She is absolutely right and I consider it as a valid critique. Feminist writing has made us aware of the gender biases in much anthropological work, including my own. I would not be able to write the same book now that I wrote in 1978. Perhaps the conditions of research prevented me from meeting women in many ways and from asking some relevant questions, but still I would write some things differently now.

[51] EJTS: Could you analyse more specifically for us the genesis and conditions of emergence of 'Kurdish studies' within the Turkish academic field? Can you see some specific breaking lines or moments in this last decade?

[52] MVB: Since the Kurds became a subject that you can publicly discuss, there have been a number of recent MA and PhD theses from Turkey that focus on Kurds. Some students sent me their dissertations; they are not all equally good but the very fact that they exist shows that the subject has moved into mainstream academic life. Some young Turkish scholars have been successful in making their work also known internationally by publishing in journals like Middle Eastern Studies; this sort of international exposure appears more difficult for people in Kurdish studies (Mesut Yeğen, who studied in London, is one of the exceptions, and there is also an 
Citation: Bruinessen, Martin Van (2006) 'I would be sitting in the village room where people gather.' Interview with Martin Bruinessen', European Journal of Turkish Studies, Thematic Issue $N^{\circ} 5$, Power, ideology, knowledge - deconstructing Kurdish Studies, URL : http://www.ejts.org/document775.html

To quote a passage, use paragraph $(\S)$

interesting piece by Fulya Atacan). It is usually people from Boğaziçi, whose supervisors have a relationship perhaps or advise them to submit a short version of their thesis to this journal and so on. People coming from elite circles seem to have a dominance in the field. They may have a greater facility in writing; they are capable of writing in certain styles that is not easily emulated by people of small town backgrounds. They have an academic habitus. Such a status distinction is very visible in Turkish academic life in general. Some people who have become quite well-known and have published much, if you look at the substance, there is nothing very special but they have a certain way of presenting it; they become more known compared to others, people who have done solid works but have not been able to publish it. Also because they have to present it in a format that is acceptable. International academic world demands you to write in a certain style, it has to be within certain paradigmatic frames.

[53] EJTS: What about Kurdish studies in Iraq?

[54] MVB: My Sorani has not developed since I did my work of the 1970s, and I find it difficult to read Sorani. I know that there are interesting publications going on in Sorani but I do not follow it. In English, I am not aware of many important new things that have come out on Iraq. There have been quite a few foreigners who have written about the current political situation in Iraq, based in Iraq, because it is relatively free to work there. People like Andrea Fischer-Tahir and Karin Mlodoch have combined academic work and NGO activities in Iraqi Kurdistan, and then you have some other foreign academics who are close to the Kurdish leadership and seem to depend on it for their information.

[55]In terms of public debate about the Kurdish situation, the Internet is now very important. I think this web-site called Kurdish media is especially important for Iraq; it gives a forum to critical voices and includes leading intellectuals like Kemal Mirawdeli. That is a website that affords itself to be critical also of the Kurdish authorities, at time.

[56] More interesting yet is perhaps what is happening in Iran. Every time I give a talk about the Kurds somewhere, I have a lot to say about the situation in Turkey, I speak about the situation in Iraq and, in the audience, someone stands up and says: 'Why haven't you spoken about East Kurdistan?' Why don't I know what is happening in East Kurdistan? I try, but it is very hard to find what is actually happening. I have not been there for a long time. I was banned from Iran for a long 
Citation: Bruinessen, Martin Van (2006) 'I would be sitting in the village room where people gather.' Interview with Martin Bruinessen', European Journal of Turkish Studies, Thematic Issue $N^{\circ} 5$, Power, ideology, knowledge - deconstructing Kurdish Studies, URL : http://www.ejts.org/document775.html

To quote a passage, use paragraph $(\S)$

time; I was able to go back to Tehran a few years ago but did not have the opportunity to visit Kurdistan. I found out there was a very lively Kurdish community in Tehran. There is a lot of publication going on in Iran. Iran has always been quite sophisticated. There are many interesting books and journals appearing in Iran. Quite a few people are doing academic work on the Kurds. They are Kurds themselves and they do a historical or geographical thesis, a thesis in development study; these are examples that came across. They often focus on their own region. The study of Kurdish society in Iran has always been more integrated in a general study of different regions in Iran. The Kurds of Iran are, in a sense, more Iranian than the Kurds of Iraq are Iraqi I think. But it is also more difficult for them to present themselves as such, to do something like 'Kurdish studies'. I am not aware of any studies about Kurdish identity or Kurdish movements, except the historical ones, memoirs. As for Iraqi Kurdistan, it is perhaps also memoirs by Iraqi Kurdish personalities that have been published in the past ten/fifteen years that are very important. On the early phases of the Kurdish movements, like the work of Mihemed Resûl Hawar on Shaykh Mahmud and on Simko, or on more recent periods the memoirs of Noshirwan (Newshîrwan Mistefa 1997a, 1997b). He is one of the leaders of PUK, who recently broke away of PUK, critical of Talabani. He was one of the major leaders of the Marxist group within PUK. He studied in Europe where he got involved in politics, and in 1977 or so he joined the guerrilla in Iraqi Kurdistan. I met him there in 1979, and I remember he was very fascinated discussing the tribal mentality. As a guerrilla leader he had to deal with tribal groups who one day supported the guerrilla and could the following day make a deal with the government and take up arms against him, and he was sincerely trying to understand, not just to condemn that phenomenon. From what I have read of his memoirs, they are interesting reflections on the experiences of an interesting life. Much of the Iraqi Kurds' writing was published in London. Iraq has this long tradition of relations with Britain, many people are partly British-trained, and many have lived in exile in London. Among Iraqi Kurdish intellectuals, you find many who think very much like European intellectuals because of this background. And these intellectuals felt that going back to live in Kurdistan would entail sacrifices, for they will not have the same liberal rights and freedoms there. They have to make many compromises if they want to go on living there. Living under a Kurdish dictatorship or Saddam Hussein's Ba'th dictatorship is different, but still. When you live there, you probably have to be very careful about what you write.

[57] EJTS: What are your projects now? Collective and personal? 
Citation: Bruinessen, Martin Van (2006) 'I would be sitting in the village room where people gather.' Interview with Martin Bruinessen', European Journal of Turkish Studies, Thematic Issue N 5 , Power, ideology, knowledge - deconstructing Kurdish Studies, URL : http://www.ejts.org/document775.html

To quote a passage, use paragraph $(\S)$

[58] MVB: I am too busy with administrative duties to have major new projects! I promised a publisher a book on identity struggles, mostly in Turkey but also in Iraq of the 1980s. But I still have not found the time to finish it. I wrote a number of articles on the subject and I wanted to develop them into a book. People have been very actively engaged in the question of their identity, where they should belong. Especially people who do not belong to the ethnic 'hard core' of the Turkish or Kurdish population, say like an Istanbul-born Alevi whose grandparents are from Erzurum and speak a Zaza dialect, have often been wresting with the question of what they 'really' are. Besides having a Turkish passport, are there other aspects of their identity that are specifically Turkish, and what are these aspects? How important is the region of origin? People from Malatya, for instance, even though they may have different languages and religions (Kurdish-Turkish, Sunni-Alevi), often show a strong mutual support when they are living elsewhere. So can hemşerilik be a stronger tie than ethnic or religious ties? Alevis have been debating what sort of an identity Alevilik is: Is it religious, is it cultural, is it political? Or perhaps also an ethnic identity? The same with Kurds, Yezidis and other minorities in Kurdistan. Turks from the region, are they really Turkish? What was Özal anyway? He was from Malatya, he had a Kurdish grandmother and his family had Naqshbandi connections. In the view of many 'western' Turks that was enough to consider him as a 'Kurd.' In his last years, when he was the President of the Republic but was pursuing a course of accommodation with the Kurds, people who were disaffected complained that 'The Kurds have occupied Çankaya!'

[59] There are these life histories: someone who starts his life as a Turk, then discovers that he is a Kurd, from a Kurd becomes a Zaza, from a Zaza becomes a Kırmanc. And who knows what he will be tomorrow? And the increasing importance of Islam as an identity, and especially what people do that is religious, I mean the rituals by which they act out their religious self-identifications, as in the case of the Sufi orders, or the reconstruction of Alevi rituals in town. These phenomena are so fascinating! Alevism used to be essentially a religion of the village; I mean you could only be an Alevi if you were in your village. The village was the religious community and the cem was the ritual of the village, and the holy places were the holy places of the village. For a long time when people moved to town, their Alevism disappeared because there was no framework for it to live. But in the 1980s, people started inventing urban Alevism. The same about Yezidis who have tried to make themselves invisible for a long time but are now also re-inventing their religion in Germany and in 
Citation: Bruinessen, Martin Van (2006) 'I would be sitting in the village room where people gather.' Interview with Martin Bruinessen', European Journal of Turkish Studies, Thematic Issue $N^{\circ} 5$, Power, ideology, knowledge - deconstructing Kurdish Studies, URL : http://www.ejts.org/document775.html

To quote a passage, use paragraph $(\S)$

Northern Iraq. And the same sort of re-inventing goes on among the Christian communities of the region.

[60] EJTS: Do you find time to go back to the region?

[61] MVB: Not as much as I would like to. When you get older, you get more responsibilities, you have students who to some extent depend on you and also administrative duties that you cannot refuse. I took part in establishing a research institute, that made my life more interesting but that also demands much of my time (International Institute for the Study of Islam in the Modern World, ISIM). I spend too much of my time doing things that I would not have to do if I were an independent researcher, and that I do not really enjoy doing, like trying to find money for the Institute but that are obviously necessary to keep the Institute going. So no, I do not have enough time to travel. I go back to Indonesia a few times a year because I have some ongoing research there, and I am setting up joint research with young Indonesian researchers. I try to go to Turkey at least every year. I have been intending to go to Iraqi Kurdistan for a long time but haven't been there yet. Inşallah this year I'm going. And Iran - that is the most under-researched part of Kurdistan. I think that if any young researcher wants to study the Kurds, I would advise her of him to go to Iran. Everything she would do there will be new because there is no recent research on Iran. Iran is unexplored. You have Kurds not only in Kurdistan but the Khorasan has a very large Kurmanci-speaking Kurdish community. It is a very interesting culture, it still shows links with the region around Tunceli, in Turkey. Again, there have been some publications but not much. So much interesting research is still to be done... 


\section{Bibliography of Martin van Bruinessen}

\section{Monographs}

(2003) Evliya Çelebi Diyarbekir'de, Derleyenler Martin van Bruinessen, Hendrik Boeschoten, Istanbul, Illetişim, [Turkish translation of Evliya Çelebi in Diyarbekir]

(2000) Kurdish Ethno-nationalism versus Nation-building States. Collected articles, Istanbul, The Isis Press.

(2000) Kürtlük, Türklük, Alevilik: etnik ve dinsel kimlik mücadeleleri, Istanbul, Illetişim Yayınları.

(2000) Mullas, Sufis and Heretics: the Role of Religion in Kurdish Society. Collected articles, Istanbul, The Isis Press.

(1999) Kitab kuning, pesantren dan tarekat: Tradisi-tradisi Islam di Indonesia, Pengantar, Abdurrahman Wahid, Third, revised edition, Bandung, Mizan, 2005.

(1998) Rakyat kecil, Islam dan politik [The little people, Islam and politics, collected articles], Yogyakarta, Bentang Budaya.

(1994) NU: tradisi, relasi-relasi kuasa, pencarian wacana baru [The NU: tradition, power relations, and the search for a new discourse], Yogyakarta, LkiS.

(1992) Tarekat Naqsyabandiyah di Indonesia. Survei historis, geografis, dan sosiologis, Pengantar, Hamid Algar, Bandung, Mizan [Revised edition: 1994]

(1992) Kürdistan üzerine yazılar, Istanbul, İletişim yayınları.

(1988) [with Hendrik Boeschoten] Evliya Çelebi in Diyarbekir. The relevant section of the Seyahatname edited with translation, commentary and introduction [= Evliya Çelebi's Book of Travels: Land and people of the Ottoman Empire in the seventeenth century. A corpus of partial editions, vol. I], Leiden, E.J. Brill.

(1978) Agha, Shaikh and State. On the Social and Political Organization of Kurdistan, Proefschrift, Rijksuniversiteit Utrecht.

(2003) Aga, Seyh, Devlet, Istanbul, Iletisim [New Turkish translation of Agha, Shaikh and State, the social and political structures of Kurdistan].

(1999) Jâmi`a-shinâsî-yi mardum-i Kurd (âghâ, shaykh u dowlat). Sâkhtârhâ-yi ijtimâ'î u siyâsî-yi Kurdistân [Persian translation of Agha, shaikh and state], Tehran, Nashr-i Pânîz.

(1996) Agha w sêx û dewlet. Bergî yekem, Sollentuna (Sweden), Solförlaget. [Kurdish (Sorani) translation (by Kurdo Ali) of Agha, shaikh and state] [Reprint: Sulaimania (Iraq): Serdem, 1999].

(1992) Agha, shaikh and state. The social and political structures of Kurdista,. London, Zed Books.

(1991) Ağa, Şeyh, Devlet-Kürdistanın Sosyal ve Politik örgütlenmesi, Ankara, Özge.

(1989) Agha, Scheich und Staat. Politik und Gesellschaft Kurdistans, Berlin, Edition Parabolis [German translation of 1978 thesis, with revisions] [Revised with a new foreword in 2003]. 
Citation: Bruinessen, Martin Van (2006) 'I would be sitting in the village room where people gather.' Interview with Martin Bruinessen', European Journal of Turkish Studies, Thematic Issue $N^{\circ} 5$, Power, ideology, knowledge - deconstructing Kurdish Studies, URL : http://www.ejts.org/document775.html

To quote a passage, use paragraph $(\S)$

\section{Contributions to collective works}

(2006) 'A Kurdish warlord on the Turkish-Persian frontier in the early twentieth century: Isma'il Aqa Simko', in, Touraj, Atabaki (ed.), Iran and the First World War: battleground of the great powers, London, I.B. Tauris, pp. 69-93.

[with Farid Wajidi] (2006), 'Syu'un ijtima'iyah and the kiai rakyat: Traditionalist Islam, civil society and social concerns', in Schulte Nordholt, Henk (ed.), Indonesian Transitions, Yogyakarta, Pustaka Pelajar, pp. 205-248.

(2005) 'Tarekat and tarekat teachers in Madurese society', in van Dijk, Kees; de Jonge, Hubb; Touwen-Bouwsma, Elly (eds.), Across Madura Strait: The dynamics of an insular society, Leiden, KITLV Press, pp. 91-117.

(2004) 'Les Kurdes, États et tribus', in Dawod, Hosham (ed.), Tribus et pouvoirs en terre d'islam, Paris, Armand Colin, pp. 145-168.

(2004) 'Post-Soeharto Muslim engagements with civil society and democratization', in Hanneman, Samuel; Schulte Nordholt, Henk (eds.), Indonesia in transition Rethinking 'civil society', 'region' and 'crisis', Yogyakarta, Pustaka Pelajar, pp. 37-66.

(2003) 'Ehmedî Xanî's Mem û Zîn and its role in the emergence of Kurdish national awareness', in Vali, Abbas (ed.), Essays on the origins of Kurdish nationalism, Costa Mesa, Mazda Publishers, pp. 40-57.

(2002) 'Back to Situbondo? Nahdlatul Ulama attitudes towards Abdurrahman Wahid's presidency and his fall', in Schulte Nordholt, Henk; Abdullah, Irwan (eds.), Indonesia: in search of transition, Yogyakarta, Pustaka Pelajar, pp. 15-46.

[Indonesian translation: 'Kembali ke Situbondo? Sikap NU terhadap kepresidenan Gus Dur', Gèrbang, Jurnal Studi Agama dan Demokrasi 12 (V), pp. 4-28.]

(2002) 'Derebeyler, şakiler (haydutlar), Aleviler: Osmanli İmparatorluğunun çevresinde (merkezden uzak yerlerde) oluşan sosyal oluşumlar Anadolu'da bir sivil toplumun oluşmasının başlangıcı mıdır?', in Bahadir, Ibrahim (ed.) Osmanli ve Cumhuriyet dönemi Alevi tarih ve kültürü, Bielefeld, Bielefeld Alevi Kültür Merkezi Yayınları, pp. 123-125.

(2002) 'Kurds, states and tribes', in Jabar, Faleh A.; Dawod, Hosham (eds.), Tribes and power: nationalism and ethnicity in the Middle East, London, Saqi, 2002, pp. 165-183. URL: http://www.let.uu.nl/ martin.vanbruinessen/personal/publications/Kurds, \%20states, \%20tribes.htm

(2001) 'Kata pengantar: tarekat dan masyarakat modern', in Sujuthi, Mahmud, Politik tarekat: Qadiriyah wa Naqsyabandiyah Jombang. Studi tentang hubungan agama, negar dan masyarakat Yogyakarta, Galang Press, pp. xiii-xvi.

(2000) 'La natura e gli usi della violenza nel conflitto kurdi', in Buttino, Marco; Ercolessi, Maria Cristina ; Triulzi, Alessandro (eds.), Uomini in armi, Napoli, l'ancora, pp. 99-113.

(2000) 'Shifting national and ethnic identities: the Kurds in Turkey and Europe', in Göksu Özdoğan, Günay; Tokay, Gül (eds.), Redefining the nation, state and citizen, Istanbul, Eren, pp. 91-108. 
Citation: Bruinessen, Martin Van (2006) 'I would be sitting in the village room where people gather.' Interview with Martin Bruinessen', European Journal of Turkish Studies, Thematic Issue N5, Power, ideology, knowledge - deconstructing Kurdish Studies, URL : http://www.ejts.org/document775.html

To quote a passage, use paragraph $(\S)$

(2000) 'Von Adela Khanum zu Leyla Zana: Weibliche Führungspersonen in der kurdischen Geschichte', in Savelsberg, Eva; Hajo, Siamend; Borck, Carsten (eds.), Kurdische Frauen und das Bild der kurdischen Frau, Münster, Lit, pp. 9-32.

(2001) 'From Adela Khanum to Leyla Zana: women as political leaders in Kurdish history', in Mojab, Shahrzad (ed.) Women of a non-state nation: the Kurds, Costa Mesa, Mazda Publishers, pp. 95-112.

(1999) 'Controversies and polemics involving the Sufi orders in twentieth-century Indonesia', in De Jong, F.; Radtke, B. (eds.), Islamic mysticism contested: thirteen centuries of controversies and polemics, Leiden, Brill, pp. 705-728.

(1999) 'Koerdisch taalpurisme', in Van der Sijs, Nicoline (ed..), Taaltrots, purisme in een veertigtal talen, Amsterdam/Antwerpen, Contact, pp. 283-284.

(1997) 'Aslini inkar eden haramzadedir!': the debate on the ethnic identity of the Kurdish Alevis', in Kehl-Bodrogi, Krisztina; Kellner-Heinkele, Barbara;Otter-Beaujean, Anke (eds.), Syncretistic religious communities in the Near East, Leiden, Brill, pp. 1-23.

(1997) 'Chapter commentaries' in Meiselas, Susan, Kurdistan in the shadow of history, New York, Random House.

(1996) 'L'Asie du sud-est', in Popovic, Alexandre; Veinstein, Gilles (eds.), Les voies d'Allah: les ordres mystiques dans le monde musulman des origines à aujourd'hui, Paris, Fayard, pp. 274-284.

(1996) 'Islamic state or state Islam? Fifty years of state-Islam relations in Indonesia', in Wessel, Ingrid (ed.), Indonesien am Ende des 20. Jahrhunderts, Hamburg, Abera-Verlag, pp. 19-34.

(1996) 'Les soufis et le pouvoir temporel', in Popovic, Alexandre; Veinstein, Gilles (eds.), Les voies d'Allah: les ordres mystiques dans le monde musulman des origines à aujourd'hui, Paris, Fayard, pp. 242-253.

(1996) 'Traditions for the future: the reconstruction of traditionalist discourse within NU', in Barton, Greg; Fealy, Greg (eds.), Nahdlatul Ulama, traditional Islam and modernity in Indonesia, Clayton, VIC, Monash Asia Institute, pp. 163-189.

(1996) [with Michiel Leezenberg] 'De Koerden in 1996', in De wereld in 1996, Uitgeverij Het Spectrum, Uitgeversmaatschappij Bonaventura en Kluwer Editorial, pp. 72-75.

(1995) 'State-Islam relations in contemporary Indonesia, 1945-1990', in van Dijk, C.; de Groot A. H. (eds.), State and Islam, Leiden, CNWS, pp. 96-114.

(1995) 'When Haji Bektash still bore the name of Sultan Sahak. Notes on the Ahl-i Haqq of the Guran district', in Popovic, Alexandre; Veinstein, Gilles (eds.), Bektachiyya: études sur l'ordre mystique des Bektachis et les groupes relevant de Hadji Bektach, Istanbul, Éditions Isis, pp. 117-138.

(1994) 'Genocide of Kurds', in Charny, Israel W. (eds), The widening circle of genocide [= Genocide: A Critical Bibliographic Review, vol 3], New Brunswick, NY, Transaction Publishers, pp. 165-191.

(1994) 'Genocide in Kurdistan? The suppression of the Dersim rebellion in Turkey (1937-38) and the chemical war against the Iraqi Kurds (1988)', in Andreopoulos, George J. (ed.), Conceptual and historical dimensions of genocide, University of Pennsylvania Press, pp. 141-170. Extracts available on: http://www.let.uu.nl/\%7Emartin.vanbruinessen/personal/publications/Dersim.pdf 
Citation: Bruinessen, Martin Van (2006) 'I would be sitting in the village room where people gather.' Interview with Martin Bruinessen', European Journal of Turkish Studies, Thematic Issue N 5 , Power, ideology, knowledge - deconstructing Kurdish Studies, URL : http://www.ejts.org/document775.html

To quote a passage, use paragraph $(\S)$

(1994) 'Pesantren and kitab kuning: continuity and change in a tradition of religious learning', in Marschall, Wolfgang (ed), Texts from the islands. Oral and written traditions of Indonesia and the Malay world [Ethnologica Bernica, 4], Berne, University of Berne, pp. 121-145.

(1993) 'Kitab kuning dan perempuan, perempuan dan kitab kuning, in Marcoes-Natsir, Lies M.; Hendrik Meuleman, Johan (eds.), Wanita Islam Indonesia dalam kajian tekstual dan kontekstual, Jakarta, INIS, pp. 165-174.

(1993) 'Kurdistan', in Krieger, Joel (ed.), The Oxford Companion to Politics of the World, New York, Oxford University Press, pp. 518-519.

(1992) 'Kurdish society, ethnicity, nationalism and refugee problems', in Kreyenbroek, Philip G.; Sperl, Stefan (eds.), The Kurds: a contemporary overview, London, Routledge, pp. 33-67.

(1991) 'Kurdish society and the modern state: ethnic nationalism versus nation-building', in: Atabaki, Turaj; Dorleijn, Margreet (eds.), Kurdistan in search of ethnic identity, Papers presented to the First Conference on Ethnicity and Ethnic Identity in the Middle East and Central Asia, Utrecht: Department of Oriental Studies, pp. 24-51.

(1991) 'The tariqa Khalwatiyya in South Celebes', in Harry A. Poeze en Pim Schoorl (eds), Excursies in Celebes. Een bundel bijdragen bij het afscheid van J. Noorduyn, Leiden, KITLV Uitgeverij, pp. 251269.

(1990) 'The Naqshbandi order in 17th-century Kurdistan', in Gaborieau, Marc; Popovic, Alexandre; Zarcone, Thierry (eds.), Naqshbandis: cheminements et situation actuelle d'un ordre mystique musulman, Istanbul-Paris, Editions Isis, pp. 337-360.

(1989) 'The ethnic identity of the Kurds', in Andrews, Peter Alford; Benninghaus, Rüdiger (eds.) Ethnic groups in the Republic of Turkey, [=Beihefte zum Tübinger Atlas des Vorderen Orients, Reihe B, Nr.60], Wiesbaden, Dr. Ludwich Reichert, 1989, pp. 613-21.

(1988) 'De tarekat in Indonesië: tussen rebellie en aanpassing, in van Dijk, C. (ed.), Islam en politiek in Indonesië, Muiderberg, Coutinho, pp. 69-84.

(1985) 'Die türkische Republik: ein säkulierter Staat?' in Blaschke, Jochen; van Bruinessen, Martin (eds.), Islam und Politik in der Türkei [=Jahrbuch zur Geschichte und Gesellschaft des Vorderen und Mittleren Orients 1984], Berlin, Express Edition [reprinted Berlin, Parabolis, 1989], pp. 13-51.

(1985) 'Vom Osmanismus zum Separatismus: Religiöse und ethnische Hintergründe der Rebellion des Scheich Said, in Blaschke, Jochen; van Bruinessen, Martin (eds.), Islam und Politik in der Türkei [=Jahrbuch zur Geschichte und Gesellschaft des Vorderen und Mittleren Orients 1984], Berlin, Express Edition [reprinted Berlin, Parabolis, 1989], pp. 109-165.

(1984) 'Popular Islam, Kurdish nationalism and rural revolt: The rebellion of Shaikh Said in Turkey (1925)', in Bak, János M.; Benecke, Gerhard (eds.), Religion and Rural Revolt, Manchester, Manchester University Press, 281-295.

(1983) 'Kurdish tribes and the state in Iran: The case of Simko's revolt', in Tapper, Richard (ed.), The Conflict of Tribe and State in Iran and Afghanistan, London, Croom Helm, pp. 364-400.

(1982) [with Koopmans, Rudy; Smit, Wicher; van Velzen, Leo], Turkije in crisis: Een sociale, politieke en economische analyse, Bussum/Antwerpen, Het Wereldvenster. 
Citation: Bruinessen, Martin Van (2006) 'I would be sitting in the village room where people gather.' Interview with Martin Bruinessen', European Journal of Turkish Studies, Thematic Issue $N^{\circ} 5$, Power, ideology, knowledge - deconstructing Kurdish Studies, URL : http://www.ejts.org/document775.html

To quote a passage, use paragraph $(\S)$

(1981) 'Nationalismus und religiöser Konflikt: Der kurdische Widerstand im Iran', in Greussing, Kurt (ed.), Religion und Politik im Iran [=Mardom nameh, Jahrbuch zur Geschichte und Gesellschaft des Mittleren Orients], Frankfurt a.M., Syndikat, pp. 372-409.

\section{Forewords and Prefaces}

(2006) 'Foreword', in, Wadie, Jwaideh, The Kurdish national movement, its origins and development. Syracuse, NY, Syracuse University Press, pp. ix-xiv.

(2004) 'NU: Jamaah konservatif yang melahirkan gerakan progresif', foreword in Laode, Ida, NU Muda: Kaum progresif dan sekularisme baru, Jakarta, Erlangga, pp. xii-xvii.

(2003) 'Gerakan usroh di Indonesia: peristiwa Lampung', preface to Syukur, Abdul, Gerakan Usroh di Indonesia: Peristiwa Lampung 1989, Yogyakarta, Ombak, pp. xix-xxiii.

(2002) 'Foreword' in Noor, Farish A., New voices of Islam, Leiden, ISIM, pp. vii-ix.

(2002) 'Het Koerdisch, een problematische taal' / 'Kurdî, zimanekî bi derd e', foreword to: Qilorî, Mahabad B.; Qilorî, Nêçîrvan, Ferhenga Kurdî - Holendî / Woordenboek Koerdisch - Nederlands,

Amsterdam, Bulaaq, pp. 5-13, pp. 14-21. URL: http://www.let.uu.nl/ martin.vanbruinessen/personal/publications/koerdisch-woordenboekvoorwerk.pdf

(2001) 'Préface', in Bougarel, Xavier; Clayer, Nathalie (eds.), Le nouvel islam balkanique: les musulmans, acteurs du post-communisme 1990-2000, Paris, Maisonneuve \& Larose, pp. 5-6.

\section{Articles in Journals}

(2006) Arabisering van de Indonesische islam?', ZemZem, Tijdschrift over het Midden-Oosten, Noord-Afrika en islam (21), pp. 73-84.

(2006) 'Nurcholish Madjid: Indonesian Muslim intellectual', ISIM Review 17, pp. 22-23.

(2005) 'Kurdish challenges', in Posch, Walter (ed.), Looking into Iraq [Chaillot paper no. 79]. Paris, Institute for Security Studies, European Union, pp. 45-72. URL: http://www.let.uu.nl/ martin.vanbruinessen/personal/publications//raq_paper_ISS.htm

(2004) 'The Kurdish movement: issues, organization, mobilization', On the Waterfront, Newsletter of the Friends of the International Institute for Social History 8, pp. 10-12. URL: http://www.let.uu.nl/ martin.vanbruinessen/personal/publications/kurds IISH talk.htm

(2003) 'Innerkurdische Herrschaftsverhältnisse: Stämme und religiöse Brüderschaften', in epdDokumentation $\quad 7, \quad$ pp. $9-14 . \quad$ URL: http://www.let.uu.nl/ martin.vanbruinessen/personal/publications/innerkurdische_herrschaft.htm

(2002) 'Genealogies of Islamic radicalism in post-Suharto Indonesia', South East Asia Research 10 (2), pp. 117-154.

(2002) 'The violent fringes of Indonesia's Islam', ISIM Newsletter 11, p. 7. 
Citation: Bruinessen, Martin Van (2006) 'I would be sitting in the village room where people gather.' Interview with Martin Bruinessen', European Journal of Turkish Studies, Thematic Issue N 5 , Power, ideology, knowledge - deconstructing Kurdish Studies, URL : http://www.ejts.org/document775.html

To quote a passage, use paragraph $(\S)$

(2001) 'Asını inkar eden haramzadedir! Le débat sur l'identité ethnique des Alévis kurdes', Études kurdes 3, pp. 7-40.

(2001) 'İsmail Beşikçi: Türk sosiologu, Kemalizm eleştirmeni ve Kürdolog', İkinci Bilim ve Siyaset 1 (1), pp. 39-52.

(2005) 'Ismail Beşikçi: Turkish sociologist, critic of Kemalism, and kurdologist', The Journal of Kurdish Studies 5, pp. 19-34.

URL: http://www.let.uu.nl/\%7Emartin.vanbruinessen/personal/publications/ismail_besikci.htm

(2001) 'The production of Islamic knowledge in western Europe', ISIM Newsletter 8, p. 3.

(2000) 'Les Kurdes, États et tribus', Études kurdes 1, pp. 9-31.

(2000) 'Kurdistan in the 16th and 17th centuries, as reflected in Evliya Celebi's Seyahatname', The Journal of Kurdish Studies 3, pp. 1-11. URL : http://www.let.uu.nl/\%7Emartin.vanbruinessen/personal/publications/Evliya Celebi Kurdistan.htm

(2000) 'The Qâdiriyya and the lineages of Qâdirî shaykhs among the Kurds', in Zarcone, Thierry; Işın, Ekren; Buehler, Arthur (eds.), The Qâdiriyya Order [=Journal of the History of Sufism, special issue, vol. 1-2], Istanbul, Simurg, pp. 131-149.

(2000) 'The Sâdatê Nehrî or Gîlânîzâde of Central Kurdistan', in Zarcone, Thierry; Işın, Ekren; Buehler, Arthur (eds.), The Qâdiriyya Order [=Journal of the History of Sufism, special issue, vol. 1-2], Istanbul, Simurg, pp. 79-91.

(2000) 'Shaykh 'Abd al-Qâdir al-Jîlânî and the Qâdiriyya in Indonesia', in Zarcone, Thierry; Işın, Ekren; Buehler, Arthur (eds.), The Qâdiriyya Order [=Journal of the History of Sufism, special issue, vol. 1-2], Istanbul, Simurg, pp. 361-395.

(2000) 'Transnational aspects of the Kurdish question', Working paper, Robert Schuman Centre for Advanced Studies, European University Institute, Florence, 33 pp. URL: http://www.let.uu.nl/ martin.vanbruinessen/personal/publications/transnational Kurds.htm

(1999) 'Global and local in Indonesian Islam', Southeast Asian Studies. 37 (2), pp. 46-63.

[Indonesian translation: 'Islam lokal dan Islam global di Indonesia', Tashwirul Afkar, Jurnal refleksi Pemikiran Keagamaan \& Kebudayaan14 (2003), pp. 68-85.]

(1999) 'The Kurds and Islam', Working Paper 13, Islamic Area Studies Project, Tokyo, 24 p.

(1999) 'The Kurds in movement: migrations, mobilisations, communications and the globalisation of the Kurdish question', Working Paper no. 14, Islamic Area Studies Project, Tokyo, 20 p. URL: http://www.let.uu.nl/ martin.vanbruinessen/personal/publications/Kurds_in_movement.htm

(1998) 'Bibliographie sélective de l'islam kurde', Les Annales de l'autre Islam.5, pp. 371-382.

(1998) 'The impact of Kurdish 'ulama on Indonesian Islam', Les Annales de l'autre Islam 5, pp.83106.

(1998) 'Introduction: The Kurds and Islam', Les Annales de l'autre Islam 5, [edited with Joyce Blau, Islam des Kurdes], pp. 13-35. URL: http://www.let.uu.nl/\%7Emartin.vanbruinessen/personal/publications/Kurds and Islam.htm 
Citation: Bruinessen, Martin Van (2006) 'I would be sitting in the village room where people gather.' Interview with Martin Bruinessen', European Journal of Turkish Studies, Thematic Issue $N^{\circ} 5$, Power, ideology, knowledge - deconstructing Kurdish Studies, URL : http://www.ejts.org/document775.html

To quote a passage, use paragraph $(\S)$

(1998) 'The Shabak, a Kizilbash community in Iraqi Kurdistan', Les Annales de l'autre Islam 5, pp. 185-196.

(1998) 'Shifting national and ethnic identities: the Kurds in Turkey and the European diaspora', Journal of Muslim Minority Affairs 18 (1), pp. 39-52.

(1998) 'Studies of Sufism and the Sufi orders in Indonesia', Die Welt des Islams 38 (2), pp. 192-219.

(1997) 'A note on source materials for the biographies of Southeast Asian 'ulama', La transmission du savoir dans le monde musulman périphérique, Lettre d'information 17, pp. 57-66.

(1996) 'Diversity and division among the Kurds', War report, bulletin of the institute for war and peace reporting 47, pp. 29-32.

(1996) 'Kurds, Turks, and the Alevi revival in Turkey', Middle East Report 200, pp. 7-10.

(1996) 'Sûfîs and sultâns in Southeast Asia and Kurdistan: a comparative survey', Studia Islamika 3 (3), pp. 1-20.

(1996) 'Turkey's death squads', Middle East Report 199, 20-23.

(1995) 'Muslim fundamentalism: something to be understood or to be explained away?', Islam and Muslim Christian Relations 6 (2), pp.157-71.

(1995) 'Shari'a court, tarekat and pesantren: religious institutions in the Banten sultanate', Archipel 50, $\quad$ pp. 165-200. URL: http://www.let.uu.nl/ martin.vanbruinessen/personal/publications/Banten_religious_institutions.htm

(1994) 'Najmuddin al-Kubra, Jumadil Kubra and Jamaluddin al-Akbar: Traces of Kubrawiyya influence in early Indonesian Islam', Bijdragen tot de Taal-, Land- en Volkenkunde 150, pp. 305-329. URL: http://www.let.uu.nl/ martin.vanbruinessen/personal/publications/Jumadil_Kubral.htm

(1994) 'Nationalisme kurde et ethnicités intra-kurdes', Peuples Méditerranéens 68-69, pp. 11-37. URL of the original English version: http://www.let.uu.nl/\%7Emartin.vanbruinessen/personal/publications/Competing_Ethnic_Loyalties.ht $\underline{\mathrm{m}}$

(1994) 'The origins and development of Sufi orders (tarekat) in Southeast Asia', Studia Islamika Indonesian Journal for Islamic Studies 1 (1), pp. 1-23.

(1994) 'Yahudi sebagai simbol dalam wacana Islam Indonesia masa kini', in Spiritualitas baru: Agama dan aspirasi rakyat [Seri Dian II Tahun I], Yogyakarta, Dian/Interfidei, pp. 253-268. URL: http://www.let.uu.nl/ martin.vanbruinessen/personal/publications/yahudi_sebagai_simbol.htm

(1993) 'Matriarchy in Kurdistan? Women rulers in Kurdish history', The International Journal of Kurdish Studies 6 (1-2), pp. 25-39.

(1992) 'Gerakan sempalan di kalangan umat Islam Indonesia: latar belakang sosial-budaya', Ulumul

Qur'an III (1), pp. 16-27. URL: http://www.let.uu.nl/ martin.vanbruinessen/personal/publications/gerakan_sempalan.htm

(1992) 'Kurdish 'ulama and their Indonesian students', in De Turcicis aliisque rebus commentarii Henry Hofman dedicati [Utrecht Turcological Series, vol 3], Utrecht, Instituut voor Oosterse Talen en Culturen, pp. 205-227. 
Citation: Bruinessen, Martin Van (2006) 'I would be sitting in the village room where people gather.' Interview with Martin Bruinessen', European Journal of Turkish Studies, Thematic Issue N 5 , Power, ideology, knowledge - deconstructing Kurdish Studies, URL : http://www.ejts.org/document775.html

To quote a passage, use paragraph $(\S)$

(1992) 'Tarekat dan politik: Amalan untuk dunia atau akherat?', Pesantren IX (1), pp. 3-14.

(1991) 'The 28th congress of the Nahdlatul Ulama: Power struggle and social concerns', Archipel 41, 185-200.

URL:

http://www.let.uu.nl/ martin.vanbruinessen/personal/publications/tarekat_dan_politik.htm

(1991) 'Haji Bektash, Sultan Sahak, Shah Mina Sahib and various avatars of a running wall', Turcica 21-23, pp. 55-69.

(1991) 'Religion in Kurdistan', Kurdish Times 4 (1-2), pp. 5-27.

(1990) 'Indonesia's ulama and politics. Caught between legitimising the status quo and searching for alternatives', Prisma - The Indonesian Indicator 49, pp. 52-69. URL: http://www.let.uu.nl/ martin.vanbruinessen/personal/publications/Ulama_and_politics.htm

(1990) 'Kitab Kuning: Books in Arabic script used in the pesantren milieu. Comments on a new collection in the KITLV library', Bijdragen tot de Taal-, Land- en Volkenkunde 146, pp. 226-269.

(1990) 'The Kurds in Turkey: Further restrictions of basic rights', The Review (International Commission of Jurists) 45, pp. 46-52.

(1990) 'Mencari ilmu dan pahala di Tanah Suci: Orang Nusantara naik haji', Ulumul Qur'an 2 (5), pp. 4249.

URL:

http://www.let.uu.nl/ martin.vanbruinessen/personal/publications/mencari_ilmu_dan_pahala.htm

(1990) 'The origins and development of the Naqshbandi order in Indonesia', Der Islam 67, pp. 150179.

(1985) 'Islam en politiek in Indonesië: spanningen en heroriëntaties', Internationale Spectator 39(8), pp. 484-494.

(1985) 'Onyedinci yüzyilda Kürtler ve dilleri: Kürt lehçeleri üzerine Evliya Çelebi'nin notları', Studia Kurdica 1-3, 13-37.

(1985) [with Blaschke, Jochen] (eds.), Islam und Politik in der Türkei [=Jahrbuch zur Geschichte und Gesellschaft des Vorderen und Mittleren Orients 1984], Berlin, Express Edition. [reprinted Berlin, Parabolis, 1989].

(1984) 'The Kurds in Turkey', MERIP Reports 121, pp. 6-12.

(1982) 'Turkijes generaals en de overgang naar een nieuwe civiele orde, Internationale Spectator 36 (12), pp. 727-734.

(1981) 'Irans Koerden en de islamitische revolutie', in De Iraanse Revolutie: Achtergronden [=MOI$\begin{array}{lllll}\text { publicatie 5], Nijmegen, } & \text { MOI, } & \text { 95-120. } & \text { URL: }\end{array}$ http://www.let.uu.nl/\%7Emartin.vanbruinessen/personal/publications//ran Koerden en revolutie.htm

(1979) 'The Christians of eastern Turkey, the state and the local power structure', ICMC Migration News 3-4, pp. 40-46. 
Citation: Bruinessen, Martin Van (2006) 'I would be sitting in the village room where people gather.' Interview with Martin Bruinessen', European Journal of Turkish Studies, Thematic Issue N ${ }^{\circ}$, Power, ideology, knowledge - deconstructing Kurdish Studies, URL : http://www.ejts.org/document775.html

To quote a passage, use paragraph $(\S)$

\section{Articles in Encyclopaedias and Dictionaries}

(2004) 'Kurdistan Workers Party (PKK)", in Mattar, Philip et al. (eds.) Encyclopedia of the Modern Middle East and North Africa, 2d ed., Detroit, Thomson Gale, vol. 2, pp. 1342-44.

(2001) 'Kurdistan', in Krieger, Joel (ed.), The Oxford Companion to Politics of the World, Second revised edition, New York, Oxford University Press, pp. 479-480.

(2000) 'Homogene natie of multi-etnische samenleving? Turkije en de Koerdische kwestie', Justitiële $\begin{array}{lllll}\text { Verkenningen } & 26 & \text { (8), } & \text { 33-44. } & \text { URL: }\end{array}$ http://www.let.uu.nl/ martin.vanbruinessen/personal/publications/homogeen.pdf

(2000) 'Kurds, genocide of', in, Charny, Israel W. (ed.), Encyclopedia of Genocide, Santa Barbara, Denver and Oxford, ABC Clio Publishers, pp. 383-385.

(1998) 'Abd al-Samad b. Muhammad Sâlih al-Kalantânî, dit Tuan Tabal', in Gaboriau, Marc et al. (eds.), Dictionnaire biographique des savants et grandes figures du monde musulman périhérique, du XIXe siècle à nos jours, fasc. 2, Paris, CNRS / EHESS, p. 9.

(1998) 'Abdul Halim Majalengka', in Gaborieau, Marc et al. (eds.), Dictionnaire biographique des savants et grandes figures du monde musulman périphérique, $d u$ XIXe siècle à nos jours, fasc. 2, Paris, CNRS / EHESS, pp. 9-10.

(1998) 'Abdurrahman Siddiq Banjari', in Gaborieau, Marc et al. (eds.), Dictionnaire biographique des savants et grandes figures du monde musulman périphérique, du XIXe siècle à nos jours, fasc. 2, Paris, CNRS / EHESS, p. 11.

(1998) 'Ahmad bin Muhammad Zain Patani', in Gaboriau, Marc et al. (eds.), Dictionnaire biographique des savants et grandes figures du monde musulman périphérique, du XIXe siècle à nos jours, fasc. 2, Paris, CNRS / EHESS, pp.13-4.

(1998) 'Ahmad Khatib Sambas', in Gaborieau, Marc et al. (eds.), Dictionnaire biographique des savants et grandes figures du monde musulman périphérique, du XIXe siècle à nos jours, fasc. 2, Paris, CNRS / EHESS, pp. 14-5.

(1998) 'Ahmad Sanusi bin Abdurrahman', in Gaborieau, Marc et al. (eds.), Dictionnaire biographique des savants et grandes figures du monde musulman périphérique, du XIXe siècle à nos jours, fasc. 2, Paris, CNRS / EHESS, pp. 15-6.

(1998) 'Ahmad Surkati', in Gaborieau, Marc et al. (eds.), Dictionnaire biographique des savants et grandes figures du monde musulman périphérique, du XIXe siècle à nos jours, fasc. 2, Paris, CNRS I EHESS, pp. 16-7.

(1998) 'Da'ud Patani', in Gaborieau, Marc et al. (eds.), Dictionnaire biographique des savants et grandes figures du monde musulman périphérique, du XIXe siècle à nos jours, fasc. 2, Paris, CNRS I EHESS, pp. 19-20.

(1998) 'Fatimah al-Banjari', in Gaborieau, Marc et al. (eds.), Dictionnaire biographique des savants et grandes figures du monde musulman périphérique, du XIXe siècle à nos jours, fasc. 2, Paris, CNRS I EHESS, pp. 20-1. 
Citation: Bruinessen, Martin Van (2006) 'I would be sitting in the village room where people gather.' Interview with Martin Bruinessen', European Journal of Turkish Studies, Thematic Issue N5, Power, ideology, knowledge - deconstructing Kurdish Studies, URL : http://www.ejts.org/document775.html

To quote a passage, use paragraph $(\S)$

(1998) 'Machrus Ali', in Gaborieau, Marc et al. (eds.), Dictionnaire biographique des savants et grandes figures du monde musulman périhérique, du XIXe siècle à nos jours, fasc. 2, Paris, CNRS I EHESS, pp. 21-2.

(1998) 'Muhammad As`ad Bugis', in Gaborieau, Marc et al. (eds.), Dictionnaire biographique des savants et grandes figures du monde musulman périhérique, du XIXe siècle à nos jours, fasc. 2, Paris, CNRS I EHESS, pp. 22-3. URL: http://www.let.uu.nl/ martin.vanbruinessen/personal/publications/muhammad_asad_bugis.htm

(1998) 'Muslikh of Mranggen', in Gaborieau, Marc et al. (eds.), Dictionnaire biographique des savants et grandes figures du monde musulman périhérique, du XIXe siècle à nos jours, fasc. 2, Paris, CNRS $1 \quad$ EHESS, 23-4. http://www.let.uu.nl/ martin.vanbruinessen/personal/publications/Muslikh_Mranggen.htm

(1998) 'Nafis al-Banjari', in Gaborieau, Marc et al. (eds.), Dictionnaire biographique des savants et grandes figures du monde musulman périphérique, du XIXe siècle à nos jours, fasc. 2, Paris, CNRS I EHESS, pp. 24-5.

(1998) 'Saleh Darat', in Gaboriau, Marc et al. (eds.), Dictionnaire biographique des savants et grandes figures du monde musulman périphérique, $d u$ XIXe siècle à nos jours, fasc. 2, Paris, CNRS I EHESS, pp. 25-6.

(1998) 'Zayn al-'Abidin b. Muhammad al-Fatani', in Gaboriau, Marc et al. (eds.), Dictionnaire biographique des savants et grandes figures du monde musulman périhérique, du XIXe siècle à nos jours, fasc. 2, Paris, CNRS / EHESS, p. 27.

(1992) 'Basyuni 'Imran', in Dictionnaire biographique des savants et grandes figures du monde musulman périphérique, du XIXe siècle à nos jours, Fasc. no 1, Paris, CNRS-EHESS, p. 26.

(1992) 'Mahfuz b. 'Abd Allah al-Tarmasi', in Dictionnaire biographique des savants et grandes figures du monde musulman périphérique, du XIXe siècle à nos jours, Fasc. no 1, Paris, CNRS-EHESS, pp. 30-31.

(1992) 'Muhammad Wali al-Khalidi', in Dictionnaire biographique des savants et grandes figures du monde musulman périphérique, du XIXe siècle à nos jours, Fasc. no 1, Paris, CNRS-EHESS, pp. 33.

(1992) 'Muhammad Zayn al-Din b. Badawi al-Sumbawi', in Dictionnaire biographique des savants et grandes figures du monde musulman périphérique, du XIXe siècle à nos jours, Fasc. no 1, Paris, CNRS-EHESS, p. 33.

(1992) 'Usman Pontianak', in Dictionnaire biographique des savants et grandes figures du monde musulman périphérique, du XIXe siècle à nos jours, Fasc. no 1, Paris, CNRS-EHESS, p. 36.

\section{Varia}

(1999) 'Die Türkei, Europa und die Kurden nach der Festnahme von Abdullah Öcalan', INAMO, Informationsprojekt Naher und Mittlerer Osten 18, pp. 9-15. (Reprinted as 'Öcalans Balance zwischen den 'Zivilisten' und den 'Militärs', Frankfurter Rundschau, 11. Juni 1999.

(1999) 'Öcalan capturé: et après? Une question kurde plus épineuse que jamais', Critique internationale 4, 39-47. 
Citation: Bruinessen, Martin Van (2006) 'I would be sitting in the village room where people gather.' Interview with Martin Bruinessen', European Journal of Turkish Studies, Thematic Issue $N^{\circ} 5$, Power, ideology, knowledge - deconstructing Kurdish Studies, URL : http://www.ejts.org/document775.html

To quote a passage, use paragraph $(\S)$

(1998) 'Apo in Italië: Europa en de PKK', Midden-Oosten tijdschrift Soera 6 (4), pp. 3-8. URL: http://www.let.uu.nl/\%7Emartin.vanbruinessen/personal/publications/Apo_in_Italie.htm

\section{Contributions in Reports}

(1996) 'Historical background', in Violations of human rights in Turkish Kurdistan, Report of a factfinding mission of Pax Christi and the Netherlands Kurdistan Society to Newroz 1993, Amsterdam, Netherlands Kurdistan Society, pp. 1-8.

(1996) 'Developments since Newroz 1993', in Violations of human rights in Turkish Kurdistan, Report of a fact-finding mission of Pax Christi and the Netherlands Kurdistan Society to Newroz 1993, Amsterdam, Netherlands Kurdistan Society, pp 22-33.

Ahmed, Kemal Mazhar (1992) Birinci Dünya Savaşı Yıllarında Kürdistan, Ankara, Berhem.

Aksoy, Gürdal (1996) Tarihi Yazılmayan Halk Kürtler, İstanbul, Avesta.

Aksoy, Gürdal (1998) Bir Sölence bir Tarih: Newroz, Ankara, Yurt Kitap-Yayın.

Aksoy, Gürdal (2002) Halklar hapishanesi Anadolu. Kürtlerde Anadolumerkezci yabancılaşma, İstanbul, Komal.

Atacan, Fulya (2001) 'A Kurdish Islamist group in modern Turkey: shifting identities', Middle Eastern Studies 37, pp. 111-44.

Beşikçi, İsmail (1969) Doğu Anadolu Düzeni Sosyo Ekonomik ve Etnik Temeller, Ankara, E yayınları.

Beysanoğlu, Şevket (1957-78) Diyarbakırı Fikir ve Sanat Adamları, Istanbul/Ankara, 3 vol.

Beysanoğlu, Şevket (1962) Diyarbakır Coğrafyası, İstanbul.

Beysanoğlu, Şevket (1990) Anıtları ve Kitâbeleri ile Diyarbakır Tarihi, Ankara.

Fischer-Tahir, Andrea (2003) 'Wir gaben viele Märtyrer': Widerstand und kollktive Identitätsbildung in Irakisch-Kurdistan, Münster, Unrast.

Hawar, Mihemed Resûl (1990-91) Shêkh Mehmûdî qareman û dewletekey khwarûy Kurdistan, London, 2 vol.

Hawar, Mihemed Resûl (1995) Simko (Îsma'îl Agha-y Shikak) û bizûtnewe-y netewayetî-y Kurd, Stockholm, Apec.

Hütteroth, Wolfgang D. (1959) Bergnomaden und Yaylabauern im mittleren kurdischen Taurus, dissertation, Marburg.

Hütteroth Wolfgang D. (1961) 'Beobachtungen zur Sozialstruktur kurdischer Stämmeim ostlischen Taurus', Zeitschrift für Ethnologie 86, pp. 23-42.

Jongerden, Joost (2006) 'Contested spaces in landscapes of violence: displacement and return in Diyarbakir at the turn of the 21st century', Kurdische Studien 4-5, pp. 61-89.

Jongerden, Joost (2006) Settlement wars: an historical analysis of displacement and return in the Kurdistan region of Turkey at the turn of the 21 st century, Ph.D. thesis, Wageningen Universiteit. 
Citation: Bruinessen, Martin Van (2006) 'I would be sitting in the village room where people gather.' Interview with Martin Bruinessen', European Journal of Turkish Studies, Thematic Issue N 5 , Power, ideology, knowledge - deconstructing Kurdish Studies, URL : http://www.ejts.org/document775.html

To quote a passage, use paragraph $(\S)$

Jwaideh, Wadie (1960) The Kurdish nationalist movement: its origins and development, Ph.D. thesis, Syracuse University.

Jwaideh, Wadie (1999) Kürt Milliyetçiliğinin Tarihi. Kökenleri ve Gelişimi, Istanbul, lletişim.

Kızılkaya, Muhsin (1991) Eski zaman eskiyaları. Yazılmamış gayrı resmi tarih, Istanbul, Sel Yayıncilık.

Kreyenbroek, Philip G.; Sperl, Stefan (eds.) (1992) The Kurds: A contemporary overview, London, Routledge.

Leezenberg, Michiel (1997) 'Irakisch-Kurdistan seit dem Zweiten Golfkrieg', in Borck, Carsten; Savelsberg, Eva; Hajo, Siamend (eds.), Ethnizität, Nationalismus, Religion und Politik in Kurdistan, Münster, Lit, pp. 45-78.

Leezenberg, Michiel (1997) 'Between assimilation and deportation: the Shabak and the Kakais in northern Iraq', in Kehl-Bodrogi, K.; Kellner-Heinkele B.; Otter-Beaujean A. (eds.), Syncretistic religious communities in the Near East, Leiden, Brill, pp. 175-194.

Leezenberg, Michiel (2003) 'Kurdish Alevis and the Kurdish nationalist movement in the 1990s', in White, Paul J.; Jongerden, Joost (eds.), Turkey's Alevi enigma. A comprehensive overview, Leiden, Brill, pp. 197-212.

Malmîsanij (1991) Said-i Nursi ve Kürt sorunu, İstanbul, Doz Yayınları.

Malmîsanij (1994) Cizira Botanlı Bedirhaniler ve Bedirhani ailesi derneği'nin tutanakları, Stockholm, APEC.

Malmîsanij (2002) Kürt Talebe-Hêvî Cemiyeti: ilk legal Kürt öğrenci derneği, Istanbul, Avesta.

Mlodoch-Ibrahim, Karin (2000) Mit Anfal ist unser Leben auch verschwunden'. Zur psychosozialen Situation von Anfal-Frauen in Germian, Kurdistan-Irak, Diplomarbeit, Berlin, Freie Universität Berlin.

Newshîrwan Mistefa, Emîn (1997) Le kenarî Danûbewe bo xirî Nawzeng: dîwî nawewey rûdawekanî Kurdistanî 'Îraq, London.

Newshîrwan Mistefa, Emîn (1997) Pencekan yektirî eshkênin: dîwî nawewey rûdawekanî Kurdistanî Îraq 1979-1983, London.

Olson, Robert (1993) Kürt Milliyetçiliğinin Kaynakları ve Şeyh Said İsyanı, Ankara, Özge.

Rohat (1992) Ziya Gökalp'in büyük çilesi Kürtler, Istanbul, Fırat Yayınları.

Rohat, Alakom (1998) Eski İstanbul Kürtleri (1453-1925), Istanbul, Avesta.

Rohat, Alakom (2004) Arîstokratên Kurd, Torin, Spanga, Apec.

Van Bruinessen, Martin (1991) Ağa, Şeyh, Devlet. Kürdistanın Sosyal ve Politik Örgütlenmesi, Özge, Ankara.

Van Bruinessen, Martin (1992) Agha, Shaikh and State. The Social and Political Structures of Kurdistan, London, Zed Books.

Van Bruinessen, Martin (1992) Kürdistan üzerine yazılar, Istanbul, Illetişim 
Citation: Bruinessen, Martin Van (2006) 'I would be sitting in the village room where people gather.' Interview with Martin Bruinessen', European Journal of Turkish Studies, Thematic Issue $N^{\circ} 5$, Power, ideology, knowledge - deconstructing Kurdish Studies, URL : http://www.ejts.org/document775.html

To quote a passage, use paragraph $(\S)$

Van Bruinessen, Martin (2003) Agha, Scheich und Staat. Politik und Gesellschaft Kurdistans. Berlin: Parabolis.

Van Bruinessen, Martin (2005) 'Ismail Beşikçi: Turkish sociologist, critic of Kemalism, and kurdologist', The Journal of Kurdish Studies 5, pp. 19-34. URL: http://www.let.uu.nl/\%7Emartin.vanbruinessen/personal/publications/ismail besikci.htm

Van Bruinessen, Martin; Boeschoten, Hendrik (eds.) (1988) Evliya Çelebi in Diyarbekir. The relevant section of the Seyahatname edited with translation, commentary and introduction, Leiden, Brill.

White, Paul J.; Jongerden, Joost (eds.) (2003) Turkey's Alevi enigma. A comprehensive overview, Leiden, Brill.

Yegen, Mesut (1996) 'The Turkish state discourse and the exclusion of Kurdish identity', Middle Eastern Studies, 32, pp. 216-29.

Yegen, Mesut (2004) 'Citizenship and ethnicity in Turkey', Middle Eastern Studies 40, pp. 51-66.

Yücel, Müslüm (2003) Kına ve ayna. Kürtlerde ölüm ve intihar, Istanbul, Elma. 